\title{
Rhodotorula bloemfonteinensis sp. nov., Rhodotorula eucalyptica sp. nov., Rhodotorula orientis sp. nov. and Rhodotorula pini sp. nov., yeasts isolated from monoterpene-rich environments
}

\author{
Carolina H. Pohl, Martha S. Smit and Jacobus Albertyn
}

Correspondence

Jacobus Albertyn

Albertynj@ufs.ac.za Department of Microbial, Biochemical and Food Biotechnology, University of the Free State, PO Box
339, Bloemfontein 9301, South Africa
Eucalyptus and coniferous trees are known sources of monoterpenes, including limonene, $\alpha$-pinene and $\beta$-pinene (Cook, 1992). These compounds are known to be potential plant protectants, especially against insect attack. In addition, monoterpenes impart certain sensory qualities, including fragrance, to plants (King \& Dickinson, 2003) and have found application in the fragrance, flavour and pharmaceutical industries (Pavlostathis \& Misra, 1999; King \& Dickinson, 2003). Several authors have demonstrated that yeasts are capable of biotransforming monoterpenes to yield products with desirable aromatic properties (Van Rensburg et al., 1997; Pavlostathis \& Misra, 1999; King \& Dickinson, 2000, 2003). However, the isolation of yeasts with the ability to utilize monoterpenes

Abbreviation: ITS, internal transcribed spacer.

The GenBank/EMBL/DDBJ accession numbers for the 26S rDNA D1/ D2 domain and ITS region sequences of strains CBS $8499^{\top}$, CBS 10736, CBS $8598^{\top}$, CBS $10735^{\top}$ and CBS $8594^{\top}$ are respectively EU075183, EU075184, EU075187, EU075188 and HM559718 (D1/ D2) and EU075185, EU075186, EU075189, EU075190 and HM559719 (ITS). as sole carbon and energy sources has proven difficult, due to the toxicity of many of these compounds (Nguyen Thanh et al., 2004). The latter authors reported that this problem can be overcome by using less toxic monoterpene analogues such as 1,4-disubstituted cyclohexanes as sole carbon sources for enrichments. In December 1995, they performed a series of isolation experiments using soil samples from eucalyptus plantations in Malaysia and Thailand and pine leaf litter from Bloemfontein, South Africa. Enrichments had been done using 1,4-cyclohexanedimethanol $(0.1 \% \mathrm{w} / \mathrm{v}), 1,4$-cyclohexanedicarboxylic acid $(0.1 \% \mathrm{w} / \mathrm{v})$ or 4 -aminobenzoate $(0.1 \% \mathrm{w} / \mathrm{v})$ as sole carbon sources. Fifteen isolates obtained from these enrichments were initially sent to the Centraalbureau voor Schimmelcultures (CBS) for identification, but only five could be identified to the species level based on physiological tests. These were identified as Rhodotorula philyla (CBS 8554), Rhodotorula glutinis (CBS 8587, later reclassified by the CBS as Rhodosporidium toruloides), Rhodotorula mucilaginosa (CBS 8596), Cryptococcus laurentii (CBS 8593) and Pichia subpelliculosa (CBS 8595). Five of the strains that could not be identified to the species level 
and that were able to utilize limonene vapours as a carbon source were investigated further. One of these was also identified as $R$. philyla (CBS 8589), and the others were described as members of three novel species, Rhodotorula retinophila (CBS 8446), Rhodotorula cycloclastica (CBS 8447, CBS 8448) and Rhodotorula terpenoidalis (CBS 8445) (Nguyen Thanh et al., 2004). In this study, we subjected the remaining five unidentified isolates as well as a further 20 isolates from the 1995 isolations to rDNA sequencing.

The $26 \mathrm{~S}$ rDNA D1/D2 region as well as the internal transcribed spacer (ITS) region was amplified by PCR and sequenced using primer pair NL1 (5'-GCATATCAATAAGCGGAGGAAAAG-3') and NL4 (5'-GGTCCGTGTTTCAAGACGG-3') (Kurtzman \& Robnett, 1998) and primer pair ITS4 (5' ${ }^{\prime}$-TCCTCCGCTTATTGATATGS-3') and ITS5 (5'-GGAAGTAAAAGTCGTAACAAGG-3') (White et al., 1990), respectively. Sequence analyses were performed with reference to sequences obtained from the GenBank database. Sequence alignments were done using CLUSTAL_X 2.0.11 (Larkin et al., 2007) and phylogenetic analyses were conducted with MEGA version 4 (Tamura et al., 2007) using neighbour-joining with Kimura's two-parameter distance measure. Confidence values were estimated from bootstrap analysis of 1000 replicates.

A summary of the 35 isolates identified during this and the previous study (Nguyen Thanh et al., 2004) is given in Table 1. Twelve of the 21 basidiomycetous isolates are able to utilize limonene vapours as a carbon source, although growth on limonene was sometimes variable. None of the 14 ascomycetous isolates could grow on limonene as a sole carbon source, although most of them could utilize hexadecane.

Sequence comparison of the 26S rDNA D1/D2 and ITS regions of the previously unidentified isolates from enrichments containing 1,4-cyclohexanedimethanol and 1,4-cyclocyclohexanedicarboxylic acid with related sequences indicated that they belong to two previously unknown species in the order Erythrobasidiales, class Cystobasidiomycetes (Hibbett et al., 2007), and are closely related to Sporobolomyces magnisporus. For the isolate obtained from pine litter from South Africa $\left(\right.$ CBS $\left.10735^{\mathrm{T}}\right)$, we propose the name Rhodotorula pini sp. nov. and, for the

Table 1. Isolates obtained from monoterpene-rich environments after use of 1,4-subtituted cyclohexanes as carbon sources in enrichments

CBS numbers are given for isolates deposited with the Centraalbureau voor Schimmelcultures. Isolates that have not been deposited have TVN numbers. Limonene-utilizers are underlined.

\begin{tabular}{|c|c|c|c|}
\hline Species & Isolate(s) & $\operatorname{Source}(s)^{*}$ & $\begin{array}{l}\text { Carbon source(s) for } \\
\text { enrichment } \dagger\end{array}$ \\
\hline \multicolumn{4}{|l|}{ Ascomycetes } \\
\hline Pichia anomala & TVN 327 & PLBS & $4-\mathrm{ABA}$ \\
\hline Pichia fermentans & TVN 288 & PLBS & 1,4-CHDCA \\
\hline Pichia guilliermondii & $\begin{array}{l}\text { TVN 313, TVN 320, TVN 330, TVN 331, TVN 332, } \\
\text { TVN 333, TVN 352, TVN354, TVN } 358\end{array}$ & PLBS, SEPT & 4-ABA, 1,4-CHDCA \\
\hline Pichia sp. & TVN $353 \ddagger$ & PLBS & 1,4-CHDM \\
\hline Pichia subpelliculosa & CBS $8595 \S$ & PLBS & 1,4-CHDCA \\
\hline \multicolumn{4}{|l|}{ Basidiomycetes } \\
\hline Cryptococcus laurentii & CBS 8593\$ & PLBS & $4-\mathrm{ABA}$ \\
\hline Cryptococcus sp. & TVN $297 \ddagger$ & SEPM & 1,4-CHDM \\
\hline Occultifur externus & CBS 8591, CBS 8597, CBS 8590 & PLBS & 1,4-CHDM \\
\hline Rhodotorula mucilaginosa & CBS $8596 \$$ & PLBS & 1,4-CHDM \\
\hline Rhodotorula orientis sp. nov. & CBS $8594^{\mathrm{T}}$ & SEPM & 1,4-CHDCA \\
\hline Rhodotorula philyla & CBS 8589\$, CBS 8554\$ & PLBS & 1,4-CHDM \\
\hline Rhodotorula pini sp. nov. & CBS $10735^{\mathrm{T}}$ & PLBS & 1,4-CHDM \\
\hline Rhodotorula retinophila & CBS 8446\$, TVN 351 & PLBS & 1,4-CHDCA \\
\hline Rhodotorula terpenoidalis & $\overline{\text { CBS 8445\$ }}$ & SEPM & 1,4-CHDCA \\
\hline
\end{tabular}

${ }^{\star}$ PLBS, Pine leaf litter, Bloemfontein, South Africa; SEPM, soil of a eucalyptus plantation, Malaysia; SEPT, soil of a eucalyptus plantation, Thailand. $\dagger$ 1,4-CHDCA, 1,4-Cyclohexanedicarboxylic acid; 1,4-CHDM, 1,4-cyclohexanedimethanol; 4-ABA, 4-aminobenzoate.

$\ddagger$ Still under investigation since, according to rDNA sequencing, the isolate represents a novel species.

\$Described by Nguyen Thanh et al. (2004). 
isolate obtained from the Malaysian eucalyptus plantation $\left(\mathrm{CBS} 8594^{\mathrm{T}}\right)$, we propose the name Rhodotorula orientis $\mathrm{sp}$. nov. Comparison of the D1/D2 and ITS regions of isolate CBS $8598^{\mathrm{T}}$, obtained from the pine litter enrichment containing 4-aminobenzoate as sole carbon source, with related sequences indicated that it belongs to another previously unknown species, also related to S. magnisporus. We propose the name Rhodotorula bloemfonteinensis sp. nov. for this isolate. Phylogenetic analysis using a combined dataset consisting of the D1/D2 and ITS regions supports the recognition of $R$. pini, R. orientis and $R$. bloemfonteinensis as novel species (Fig. 1). These three species can be distinguished physiologically from each other and from S. magnisporus, as indicated in Table 2. Furthermore, $R$. pini is able to grow on limonene vapours.

Nagahama et al. (2006) defined six robust subgroups within the Erythrobasidium clade (Erythrobasidiales). However, they did not include S. magnisporus in their study. Phylogenetic analysis based on a combined dataset consisting of the $26 \mathrm{~S}$ rDNA D1/D2 region and ITS domain support the six subgroups as defined by Nagahama et al. (2006), but suggest a seventh subgroup (Magnisporus), comprising the three novel species $(R$. pini, $R$. orientis and $R$. bloemfonteinensis) as well as $S$. magnisporus, with a high bootstrap value.

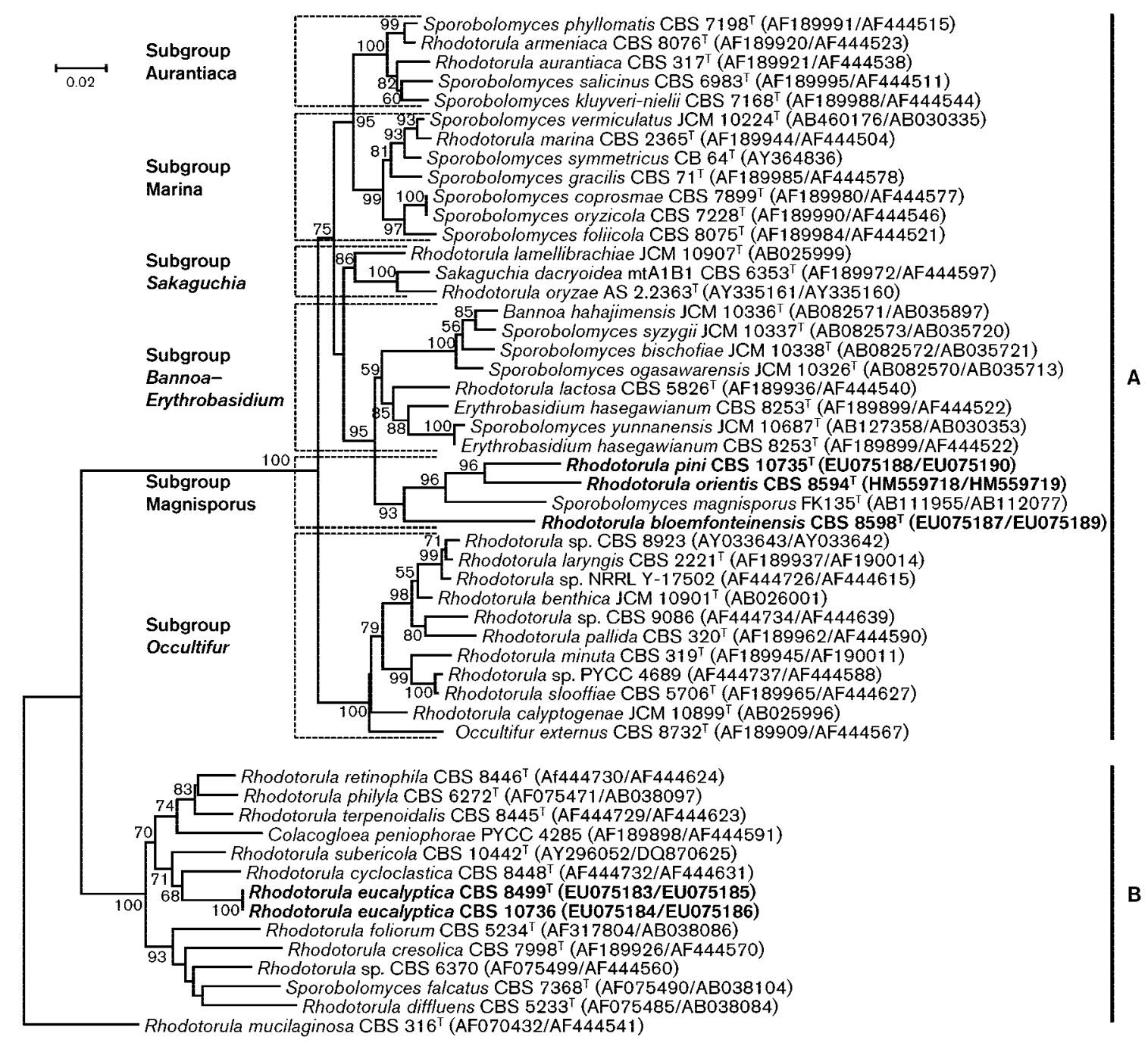

Fig. 1. Phylogenetic tree derived from neighbour-joining analysis based on a combined dataset composed of the $26 \mathrm{~S}$ rDNA $\mathrm{D} 1 / \mathrm{D} 2$ region and the ITS domain showing the placement of Rhodotorula pini sp. nov., Rhodotorula orientis sp. nov. and Rhodotorula bloemfonteinensis sp. nov. (within clade A) and Rhodotorula eucalyptica sp. nov. (within clade B) relative to related taxa. Accession numbers for sequences of the $26 \mathrm{~S}$ rDNA D1/D2 region/ITS domain are given unless deposited under a single accession number. Rhodotorula mucilaginosa $\mathrm{CBS} 316^{\top}$ was included to root the tree. In clade A, the subgroups defined by Nagahama et al. (2006) as well as our newly described seventh subgroup (Magnisporus) are indicated. Bootstrap percentages (from 1000 replicates) $\geqslant 50 \%$ are shown. Bar, $2 \%$ nucleotide sequence divergence. 
Table 2. Salient characteristics of Rhodotorula pini sp. nov., Rhodotorula bloemfonteinensis sp. nov., Rhodotorula orientis sp. nov. and Sporobolomyces magnisporus

Strains: 1, R. pini sp. nov. CBS $10735^{\mathrm{T}} ; 2$, R. bloemfonteinensis sp. nov. CBS $8598^{\mathrm{T}} ; 3$, R. orientis sp. nov. CBS $8594^{\mathrm{T}}$; 4, S. magnisporus FK $135^{\mathrm{T}}$ (data from Nakase et al., 2003). +, Positive; -, negative; w, weak

\begin{tabular}{|lcccc|}
\hline Characteristic & $\mathbf{1}$ & $\mathbf{2}$ & $\mathbf{3}$ & $\mathbf{4}$ \\
\hline Assimilation of: & & & & \\
$\quad$ Sorbose & + & - & + & $+/ \mathrm{w}$ \\
Cellobiose & + & + & + & - \\
Lactose & - & + & + & - \\
D-Arabinose & + & + & + & - \\
Citrate & + & - & + & $+/ \mathrm{w}$ \\
Nitrate & - & - & + & + \\
Nitrite & - & + & + & + \\
L-Lysine & + & - & + & - \\
Growth in vitamin-free medium & - & + & + & - \\
\end{tabular}

Based on the comparison of $26 \mathrm{~S}$ rDNA D1/D2 and ITS regions, two of the previously unidentified limoneneutilizing isolates (CBS $8499^{\mathrm{T}}$ and CBS 10736), obtained from soil from a Malaysian eucalyptus plantation, were found to be identical. Phylogenetic analysis using a combined dataset consisting of the D1/D2 and ITS regions (Fig. 1) indicated that they belong to a previously unknown species, closely related to the limonene-utilizing yeast $R$. cycloclastica, for which we propose the name Rhodotorula eucalyptica sp. nov. This newly described species and $R$. cycloclastica differ at 16 positions in the D1/D2 region and at 93 positions in the ITS domain. Phylogenetic analysis indicated that R. cycloclastica previously grouped with Rhodotorula subericola (Belloch et al., 2007) but, with the addition of R. eucalyptica, the latter species now forms a defined subgroup together with R. cycloclastica (Fig. 1). R. cycloclastica and R. eucalyptica in turn belong to a larger group of limonene-utilizing Rhodotorula species within the class Microbotryomycetes (Hibbett et al., 2007) which also includes $R$. retinophila, $R$. terpenoidalis and R. philyla (Nguyen Thanh et al., 2004). However, no information exists on the ability of Colacogloea peniophorae or $R$. subericola to utilize limonene. $R$. eucalyptica can be distinguished physiologically from $R$. cycloclastica as indicated in Table 3.

All the other Rhodotorula isolates with the ability to utilize limonene belong within a specific clade related to $R$. cycloclastica (class Microbotryomycetes) (Nguyen Thanh et al., 2004). R. pini is thus the first yeast from a distant clade (class Cystobasidiomycetes) that displays potential for growth on limonene, although growth on limonene vapours was variable in tests done on different occasions. The disubstituted cyclohexanes proved very successful for the isolation of novel Rhodotorula species, since 14 of the 35 isolates of which rDNA was sequenced represent nine novel species, of which seven belong to the genus
Table 3. Salient characteristics of Rhodotorula eucalyptica $\mathrm{sp}$. nov. and its closest relative, $R$. cycloclastica

Data for R. cycloclastica CBS $8448^{\mathrm{T}}$ were taken from Nguyen Thanh et al. (2004).

\begin{tabular}{|lcc|}
\hline Characteristic & $\begin{array}{c}\text { R. eucalyptica sp. nov. } \\
\text { CBS } 8499^{\mathrm{T}}\end{array}$ & $\begin{array}{c}\text { R. cycloclastica } \\
\text { CBS }^{\mathbf{4} 448^{\mathrm{T}}}\end{array}$ \\
\hline Assimilation of: & & \\
D-Xylose & + & - \\
Sucrose & + & - \\
Maltose & + & - \\
Melezitose & + & - \\
Arbutin & + & - \\
\hline
\end{tabular}

Rhodotorula. Five of these novel Rhodotorula species represent limonene-utilizers.

\section{Latin diagnosis of Rhodotorula pini Pohl, M. S. Smit et Albertyn sp. nov.}

In medio liquido extracto fermenti et extracto malti confecto, post dies tres ad $25^{\circ} \mathrm{C}$, cellulae cylindricae $(8.2-20.5 \times 2.8-$ $5.2 \mu \mathrm{m})$. Pseudohyphae formantur. Cellulae multipolariter gemmantes, racemosae. In agaro extracto fermenti en extracto malti confencto, post dies septem ad $25{ }^{\circ} \mathrm{C}$, cultura glabra ad farinata, margine integra, aurantiaca. Ballistosporae non formantur. In agaro Dalmau pseudohyphae formantur. Non fermentat. Glucosum, trehalosum, melezitosum (lente), Nacetylglucosaminum, glycerolum, erythritolum, mannitolum, salicinum, gluconatum, lactatum, succinatum, citratum, glucuronatum, arbutinum et limonenum (variabile) assimilantur. Galactosum, sorbosum, sucrosum, maltosum, cellobiosum, lactosum, melibiosum, raffinosum, inulinum, amylum solibile, xylosum, L-arabinosum, D-arabinosum, ribosum, rhamnosum, D-glucosaminum, ethanolum, methanolum, ribitolum, galactitolum, glucitolum, xylitolum, arabinitolum, $\alpha$-methyl-D-glucosidum, galacturonatum, inositolum, propan-1,2-diolum, butan2,3-diolum et hexadecanum non assimilantur. L-Lysinium et cadaverinum assimilantur neque nitratum, nitritum, creatininum, creatinum, imidazolum et ethylaminum. Ureum finditur. Materia amyloidea non formatur. Vitaminum externum crescentiae necessarium. Crescit in medio $0.01 \%$ cycloheximidum continente. In medio $0.1 \%$ cycloheximidum vel $1 \%$ acidum aceticum vel $50 \%$ glucosum continente non crescit. Non crescit ad $37^{\circ} \mathrm{C}$. Typus praeservatus in collectione zymotica Centraalbureau voor Schimmelcultures, Utrecht, Neerlandia (holotypus lyophilisatus CBS $10735^{\mathrm{T}}$ ) et in collectione zymotica Agricultural Research Services United States Department of Agriculture, Peoria, Illinois (isotypus NRRL Y-48410 ${ }^{\mathrm{T}}$ ).

\section{Description of Rhodotorula pini Pohl, M. S. Smit et Albertyn sp. nov.}

Rhodotorula pini (pi'ni. N.L. gen. n. pini of Pinus, referring to the association of this yeast with trees of the genus Pinus). 
In YM broth $\left(1^{-1}: 3 \mathrm{~g}\right.$ yeast extract, $3 \mathrm{~g}$ malt extract, $5 \mathrm{~g}$ peptone and $10 \mathrm{~g}$ glucose) after 3 days of growth at $25^{\circ} \mathrm{C}$, cells are elongated $(8.2-20.5 \times 2.8-5.2 \mu \mathrm{m})$ (Fig. 2a), often forming pseudohyphae. Multipolar budding is observed and cells occur as clusters. On YM agar after 7 days of growth at $25{ }^{\circ} \mathrm{C}$, colonies are smooth to slightly powdery with entire margins and orange in colour. No ballistospores are observed on cornmeal agar or YM agar. In Dalmau plate cultures, pseudohyphae can be observed. No fermentation is observed. The yeast is able to assimilate D-glucose, trehalose, melezitose (weakly), $\mathrm{N}$-acetylglucosamine, glycerol, erythritol, mannitol, salicin, D-gluconate, lactate, succinate, citrate, glucuronate, arbutin and limonene (variable), but not galactose, sorbose, sucrose, maltose, cellobiose, lactose, melibiose, raffinose, inulin, soluble starch, xylose, L- or Darabinose, ribose, rhamnose, D-glucosamine, ethanol, methanol, ribitol, galactitol, glucitol, xylitol, arabinitol, $\alpha$-methyl D-glucoside, galacturonate, inositol, propane-1,2-diol, butane-2,3-diol or hexadecane. L-Lysine and cadaverine are utilized as nitrogen sources, but not nitrate, nitrite, creatinine, creatine, imidazole or ethylamine. The yeast hydrolyses urea, but no extracellular starch is produced. Vitamins are necessary for growth. Growth is observed in the presence of $0.01 \%$ cycloheximide, but not in the presence of $0.1 \%$ cycloheximide, $1 \%$ acetic acid or $50 \%$ glucose. No growth is observed at $37^{\circ} \mathrm{C}$.

The type strain is deposited in the yeast culture collection of the Centraalbureau voor Schimmelcultures, Utrecht, The Netherlands, as CBS $10735^{\mathrm{T}}$, and a copy has been deposited in the yeast culture collection of the Agricultural Research Services, United States Department of Agriculture, Peoria, Illinois, USA (NRRL Y $-48410^{\mathrm{T}}$ ).

\section{Latin diagnosis of Rhodotorula bloemfonteinensis Pohl, M. S. Smit et Albertyn sp. nov.}

In medio liquido extracto fermenti et extracto malti confecto, post dies tres ad $25^{\circ} \mathrm{C}$, cellulae ovoidae (4.1-6.3 $\times 2.4-$ $3.0 \mu \mathrm{m})$. Cellulae polariter gemmantes, singulae vel binae cohaerentes. In agaro extracto fermenti et extracto malti confecto, post dies septem ad $25{ }^{\circ} \mathrm{C}$, cultura glabra, salmonea,
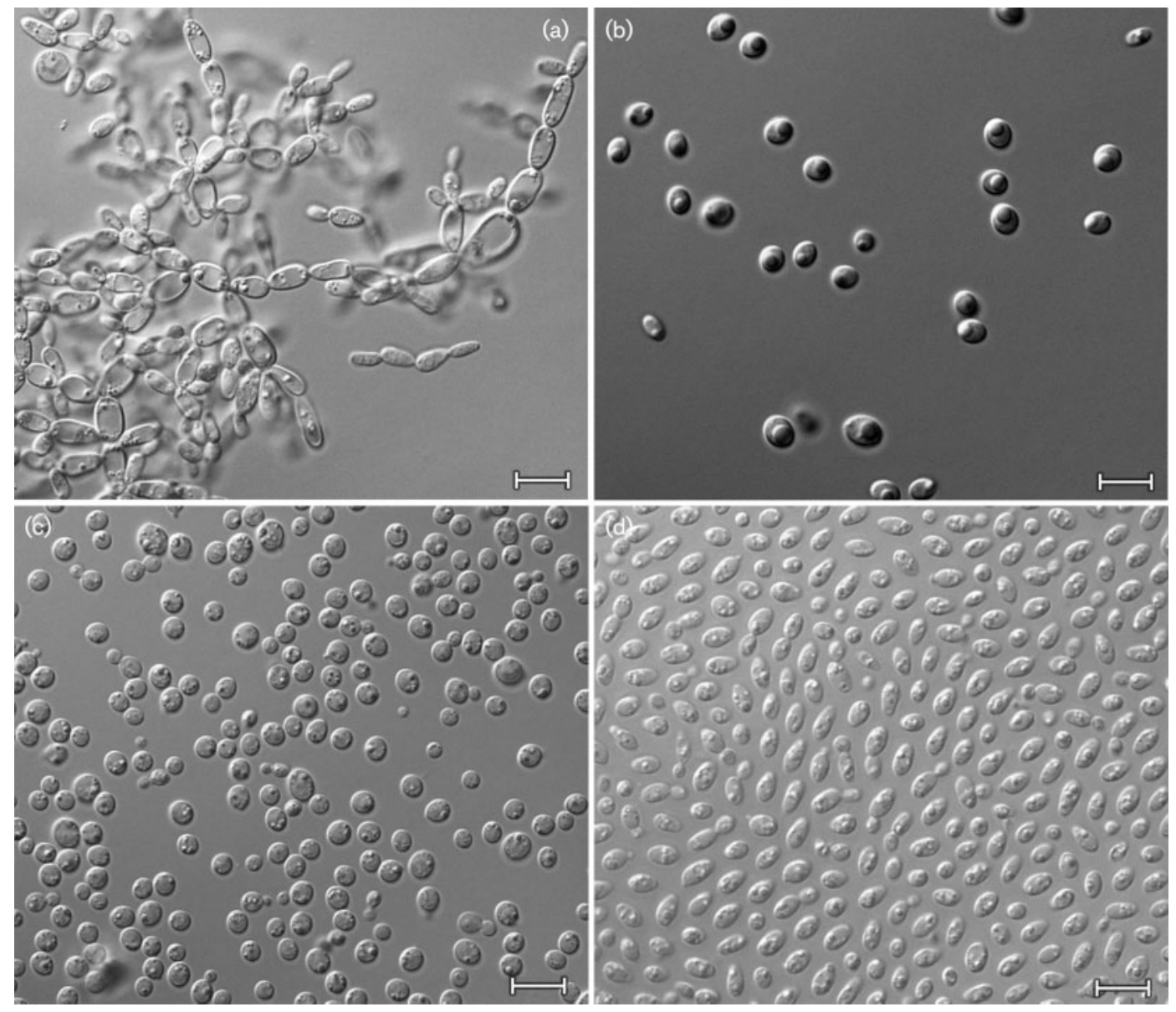

Fig. 2. Differential interference contrast micrographs of vegetative cells of Rhodotorula pini sp. nov. CBS $10735^{\top}$ (a), Rhodotorula bloemfonteinensis sp. nov. CBS $8598^{\top}$ (b), Rhodotorula orientis sp. nov. CBS $8594^{\top}$ (c) and Rhodotorula eucalyptica sp. nov. CBS $8499^{\top}$ (d) following growth in YM broth for 3 days at $25{ }^{\circ} \mathrm{C}$. Bars, $10 \mu \mathrm{m}$. 
margine integra. Ballistosporae non formantur. In agaro Dalmau nec pseudohyphae nec hyphae formantur. Non fermentat. Glucosum, sucrosum, maltosum, cellobiosum, trehalosum, lactosum, melibiosum, raffinosum, melezitosum, amylum solibile, D-arabinosum, ribosum (lente), ethanolum (lente), glycerolum, ribitolum, mannitolum (lente), glucitolum (lente), salicinum, gluconatum, lactatum, succinatum, glucuronatum, inositolum (lente) et arbutinum (lente) assimilantur. Galactosum, sorbosum, inulinum, xylosum, Larabinosum, rhamnosum, glucosaminum, $\mathrm{N}$-acetylglucosaminum, methanolum, erythritolum, galactitolum, xylitolum, arabinitolum, $\alpha$-methyl-D-glucosidum, citratum, galacturonatum, propan-1,2-diolum, butan-2,3-diolum, hexadecanum et limonenum non assimilantur. Nitritum assimilantur neque nitratum, creatininum, creatinum, imidazolum, Llysinum et ethylaminum. Urea non finditur. Materia amyloidea non formatur. Vitaminum externum crescentiae non necessarium. Crescit in medio $0.1 \%$ cycloheximidum continente. In medio $1 \%$ acidum aceticum vel $50 \%$ glucosum continente non crescit. Non crescit ad $37^{\circ} \mathrm{C}$. Typus praeservatus in collectione zymotica Centraalbureau voor Schimmelcultures, Utrecht, Neerlandia (holotypus lyophilisatus CBS $8598^{\mathrm{T}}$ ) et in collectione zymotica Agricultural Research Services United States Department of Agriculture, Peoria, Illinois (isotypus NRRL Y-48407 $7^{\mathrm{T}}$ ).

\section{Description of Rhodotorula bloemfonteinensis Pohl, M. S. Smit et Albertyn sp. nov.}

Rhodotorula bloemfonteinensis (bloem.fon.tei.nen'sis. N.L. fem. adj. bloemfonteinensis referring to Bloemfontein, South Africa, where the type strain was isolated).

In YM broth after 3 days of growth at $25{ }^{\circ} \mathrm{C}$, cells are ovoid $(4.1-6.3 \times 2.4-3.0 \mu \mathrm{m})$ (Fig. 2b). Unipolar budding is observed and cells occur singly or as parent-bud pairs. On YM agar after 7 days of growth at $25^{\circ} \mathrm{C}$, colonies are smooth with entire margins and salmon-coloured. No ballistospores are observed on cornmeal agar or YM agar. In Dalmau plate cultures, no pseudohyphae or true hyphae can be observed. No fermentation is observed. The yeast is able to assimilate glucose, sucrose, maltose, cellobiose, trehalose, lactose, melibiose, raffinose, melezitose, soluble starch, D-arabinose, ribose (weakly), ethanol (weakly), glycerol, ribitol, mannitol (weakly), glucitol (weakly), salicin, D-gluconate, lactate, succinate, glucuronate, inositol (weakly) and arbutin (weakly), but not galactose, sorbose, inulin, xylose, L-arabinose, rhamnose, D-glucosamine, $\mathrm{N}$ acetylglucosamine, methanol, erythritol, galactitol, xylitol, arabinitol, $\alpha$-methyl D-glucoside, citrate, galacturonate, propane-1,2-diol, butane-2,3-diol, hexadecane or limonene. Nitrite is utilized as a nitrogen source, but not nitrate, creatinine, creatine, imidazole, L-lysine or ethylamine. The yeast does not hydrolyse urea and no extracellular starch is produced. Vitamins are not necessary for growth. Growth is observed in the presence of $0.1 \%$ cycloheximide, but not in the presence of $1 \%$ acetic acid or $50 \%$ glucose. No growth is observed at $37{ }^{\circ} \mathrm{C}$.
The type strain is strain CBS $8598^{\mathrm{T}}\left(=\mathrm{NRRL} \mathrm{Y}-48407^{\mathrm{T}}\right)$.

\section{Latin diagnosis of Rhodotorula orientis Pohl, M. S. Smit et Albertyn sp. nov.}

In medio liquido extracto fermenti et extracto malti confecto, post dies tres ad $25{ }^{\circ} \mathrm{C}$, cellulae rotundae $(3.6-7.0 \mu \mathrm{m})$. Cellulae polariter gemmantes, singulae vel binae cohaerentes. In agaro extracto fermenti et extracto malti confecto, post dies septem ad $25{ }^{\circ} \mathrm{C}$, cultura glabra, salmonea, margine integra. Ballistosporae non formantur. In agaro Dalmau nec pseudohyphae nec hyphae formantur. Non fermentat. Glucosum, sucrosum, maltosum, cellobiosum, sorbosum, trehalosum, lactosum, melibiosum, raffinosum (lente), melezitosum, xylosum, amylum solibile (lente), D-arabinosum, Larabinosum, ribosum, ethanolum, glycerolum, mannitolum (lente), erythritolum, glucitolum, arabinitolum, salicinum, $\alpha$ methyl-D-glucosidum, gluconatum, lactatum, succinatum, citratum, glucuronatum $\mathrm{N}$-acetylglucosaminum, propan1,2-diolum, et arbutinum (lente) assimilantur. Galactosum, inulinum, rhamnosum, glucosaminum, methanolum, ribitolum, galactitolum, xylitolum, inositolum, galacturonatum, butan-2,3-diolum, hexadecanum et limonenum non assimilantur. Nitritum nitratum, cadaverinum, L-lysinum et ethylaminum assimilantur neque creatininum, creatinum et imidazolum. Urea non finditur. Materia amyloidea non formatur. Vitaminum externum crescentiae non necessarium. Crescit in medio $0.01 \%$ cycloheximidum continente. In medio $1 \%$ acidum aceticum vel $50 \%$ glucosum continente non crescit. Non crescit ad $37{ }^{\circ} \mathrm{C}$. Typus praeservatus in collectione zymotica Centraalbureau voor Schimmelcultures, Utrecht, Neerlandia (holotypus lyophilisatus CBS $8594^{\mathrm{T}}$ ) et in collectione zymotica Agricultural Research Services United States Department of Agriculture, Peoria, Illinois (isotypus NRRL Y-48719 ${ }^{\mathrm{T}}$ ).

\section{Description of Rhodotorula orientis Pohl, M. S. Smit et Albertyn sp. nov.}

Rhodotorula orientis (o.ri.en'tis. L. fem. adj. orientis eastern, referring to eastern Malaysia, where the type strain was isolated).

In YM broth after 3 days of growth at $25{ }^{\circ} \mathrm{C}$, cells are round (diameter 3.6-7.0 $\mu \mathrm{m}$ ) (Fig. 2c). Unipolar budding is observed and cells occur singly or as parent-bud pairs. On YM agar after 7 days of growth at $25^{\circ} \mathrm{C}$, colonies are smooth with entire margins and salmon-coloured. No ballistospores are observed on cornmeal agar or YM agar. In Dalmau plate cultures, no pseudohyphae or hyphae can be observed. No fermentation is observed. The yeast is able to assimilate glucose, sucrose, maltose, cellobiose, sorbose, trehalose, lactose, melibiose, raffinose (weakly), melezitose, xylose, soluble starch (weakly), D- and L-arabinose, ribose, ethanol, glycerol, mannitol (weakly), erythritol, glucitol, arabinitol, salicin, $\alpha$-methyl D-glucoside, D-gluconate, lactate, succinate, citrate, glucuronate, $N$-acetylglucosamine, propane-1,2-diol and arbutin (weakly), but not 
galactose, inulin, rhamnose, D-glucosamine, methanol, ribitol, galactitol, xylitol, inositol, galacturonate, butane2,3-diol, hexadecane or limonene. Nitrite, nitrate, cadaverine, L-lysine and ethylamine are utilized as nitrogen sources, but not creatinine, creatine or imidazole. The yeast does not hydrolyse urea and no extracellular starch is produced. Vitamins are not necessary for growth. Growth is observed in the presence of $0.01 \%$ cycloheximide, but not in the presence of $1 \%$ acetic acid or $50 \%$ glucose. No growth is observed at $37^{\circ} \mathrm{C}$.

The type strain is CBS $8594^{\mathrm{T}}$ (=NRRL Y $-48719^{\mathrm{T}}$ ).

\section{Latin diagnosis of Rhodotorula eucalyptica Pohl, M.S. Smit et Albertyn sp. nov.}

In medio liquido extracto fermenti et extracto malti confecto, post dies tres ad $25{ }^{\circ} \mathrm{C}$, cellulae ovoidae ad cylindricae (4.0$6.0 \times 4.0-8.2 \mu \mathrm{m})$. Cellulae polariter gemmantes, binae cohaerentes. In agaro extracto fermenti et extracto malti confecto, post dies septem ad $25{ }^{\circ} \mathrm{C}$, cultura aquosa mucosescens vel glutinosescens, cremea, margine integra. In agaro Dalmau nec pseudohyphae nec hyphae formantur. Non fermentat. D-Glucosum, D-glucosaminum, D-xylosum, sucrosum, maltosum, trehalosum, $\alpha$-methyl-D-glucosidum (lente), arbutinum, melezitosum, ribitolum, xylitolum, D-glucitolum, D-mannitolum, succinatum, citratum, decanum, hexadecanum et limonenum (variabile) assimilantur. D-Galactosum, L-sorbosum, D-ribosum, L-arabinosum, D-arabinosum, rhamnosum, cellobiosum, salicinum, melibiosum, lactosum, raffinosum, inulinum, amylum solibile, glycerolum, erythritolum, ribitolum, L-arabinitolum, galactitolum, inositolum, D-gluconatum, D-glucuronatum, D-galacturonatum, DL-lactatum, propan-1,2-diolum, butan-2,3-diolum non assimilantur. Crescit in ethanolo neque methanolo. L-Lysinum (lente) et ethylaminum assimilantur neque nitratum, nitritum, creatininum, creatinum, cadaverinum et imidazolum. Ureum finditur. Materia amyloidea non formatur. Vitaminum externum crescentiae non necessarium. In medio $0.01 \%$ cycloheximidum, $1 \%$ acidum aceticum, $50 \%$ glucosum continente non crescit. Non crescit ad $37^{\circ} \mathrm{C}$. Typus praeservatus in collectione zymotica Centraalbureau voor Schimmelcultures, Utrecht, Neerlandia (holotypus lyophilisatus CBS $8499^{\mathrm{T}}$ ) et in collectione zymotica Agricultural Research Services United States Department of Agriculture, Peoria, Illinois (isotypus NRRL Y-48408).

\section{Description of Rhodotorula eucalyptica Pohl, M. S. Smit et Albertyn sp. nov.}

Rhodotorula eucalyptica (eu.ca.lyp'ti.ca. N.L. fem. adj. eucalyptica of eucalyptus, referring to the association of this yeast with eucalyptus plantations).

In YM broth after 3 days of growth at $25{ }^{\circ} \mathrm{C}$, cells are ovoid to elongate $(4.0-6.0 \times 4.0-8.2 \mu \mathrm{m})$ (Fig. 2d). Polar budding is observed and cells occur as parent-bud pairs. On YM agar after 7 days at $25{ }^{\circ} \mathrm{C}$, colonies are mucoid to viscous with entire margins and cream coloured. In Dalmau plate cultures, no pseudohyphae or true hyphae can be observed. No fermentation is observed. The yeast is able to assimilate D-glucose, D-glucosamine, D-xylose, sucrose, maltose, trehalose, $\alpha$-methyl D-glucoside (weakly), arbutin, melezitose, ribitol, xylitol, D-glucitol, D-mannitol, succinate, citrate, decane, hexadecane and limonene (variable), but not D-galactose, L-sorbose, D-ribose, L- or D-arabinose, rhamnose, cellobiose, salicin, melibiose, lactose, raffinose, inulin, starch, glycerol, erythritol, ribitol, L-arabinitol, galactitol, inositol, D-gluconate, D-glucuronate, D-galacturonate, DL-lactate, propane-1,2-diol or butane-2,3-diol. Growth is observed in ethanol, but not in methanol. LLysine (weakly) and ethylamine are utilized as nitrogen sources, but not nitrate, nitrite, creatinine, creatine, cadaverine or imidazole. The yeast hydrolyses urea but no extracellular starch is produced. Vitamins are not necessary for growth. No growth is observed in the presence of $0.01 \%$ cycloheximide, $1 \%$ acetic acid or $50 \%$ glucose. No growth is observed at $37{ }^{\circ} \mathrm{C}$.

The type strain is CBS $8499^{\mathrm{T}}\left(=\mathrm{NRRL} Y-48408^{\mathrm{T}}\right)$.

\section{Acknowledgements}

The authors would like to acknowledge Vu Nguyen Thanh and Ntsane Moleleki for the initial isolation of the yeast isolates, D. Yarrow from the Centraalbureau voor Schimmelcultures for the initial physiological tests on CBS $8499^{\mathrm{T}}$ and Andri van Wyk for technical assistance with culture maintenance. This work is based upon research supported by the National Research Foundation and Department of Science and Technology under the SABI program. Any opinion, findings and conclusions or recommendations expressed in this material are those of the authors and therefore the NRF and DST do not accept any liability in regard thereto.

\section{References}

Belloch, C., Villa-Carvajal, M., Álvarez-Rodríguez, M. L. \& Coque, J. J. R. (2007). Rhodotorula subericola sp. nov., an anamorphic basidiomycetous yeast species isolated from bark of Quercus suber (cork oak). Int J Syst Evol Microbiol 57, 1668-1671.

Cook, S. P. (1992). Influence of monoterpene vapours on spruce spider mite, Oligonychus ununguis, adult females. J Chem Ecol 18, 1497-1504.

Hibbett, D. S., Binder, M., Bischoff, J. F., Blackwell, M., Cannon, P. F., Eriksson, O. E., Huhndorf, S., James, T., Kirk, P. M. \& other authors (2007). A higher-level phylogenetic classification of the Fungi. Mycol Res 111, 509-547.

King, A. J. \& Dickinson, J. (2000). Biotransformation of monoterpene alcohols by Saccharomyces cerevisiae, Torulaspora delbrueckii and Kluyveromyces lactis. Yeast 16, 499-506.

King, A. J. \& Dickinson, J. R. (2003). Biotransformation of hop aroma terpenoids by ale and lager yeasts. FEMS Yeast Res 3, 53-62.

Kurtzman, C. P. \& Robnett, C. J. (1998). Identification and phylogeny of ascomycetous yeasts from analysis of nuclear large subunit (26S) ribosomal DNA partial sequences. Antonie van Leeuwenhoek 73, 331-371.

Larkin, M. A., Blackshields, G., Brown, N. P., Chenna, R., McGettigan, P. A., McWilliam, H., Valentin, F., Wallace, I. M., Wilm, A. \& other authors (2007). CLUSTAL W and CLUSTAL_X version 2.0. Bioinformatics 23, 2947-2948. 
Nagahama, T., Hamamoto, M., Nakase, T., Shimamura, S. \& Horikoshi, K. (2006). Phylogenetic relationship within the Erythrobasidium clade: molecular phylogenies, secondary structure, and intron positions inferred from partial sequences of ribosomal RNA and elongation factor- $1 \alpha$ genes. J Gen Appl Microbiol 52, 37-45.

Nakase, T., Tsuzuki, S., Lee, F.-L., Sugita, T., Jindamorakot, S., Janngam, H., Potacharoen, W., Tanticharoen, M., Kudo, T. \& Takashima, M. (2003). Sporobolomyces magnisporus sp. nov., a new yeast species in the Erythrobasidium cluster isolated from plants in Taiwan. J Gen Appl Microbiol 49, 337-344.

Nguyen Thanh, V., Smit, M. S., Moleleki, N. \& Fell, J. W. (2004). Rhodotorula cycloclastica sp. nov., Rhodotorula retinophila sp. nov., and Rhodotorula terpenoidalis sp. nov., three limonene-utilizing yeasts isolated from soil. FEMS Yeast Res 4, 857-863.
Pavlostathis, S. G. \& Misra, G. (1999). Biotransformation of selected monoterpenes under nitrate-reducing conditions. Appl Microbiol Biotechnol 53, 63-68.

Tamura, K., Dudley, J., Nei, M. \& Kumar, S. (2007). MEGA4: molecular evolutionary genetics analysis (MEGA) software version 4.0. Mol Biol Evol 24, 1596-1599.

van Rensburg, E., Moleleki, N., van der Walt, J. P., Botes, P. J. \& van Dyk, M. S. (1997). Biotransformation of $(+)$ limonene and (-)piperitine by yeasts and yeast-like fungi. Biotechnol Lett 19, 779-782.

White, T. J., Bruns, T., Lee, S. \& Taylor, J. W. (1990). Amplification and direct sequencing of fungal ribosomal RNA genes for phylogenetics. In PCR Protocols: a Guide to Methods and Applications, pp. 315-322. Edited by M. A. Innis, D. H. Gelfand, J. J. Sninsky \& T. J. White. San Diego: Academic Press. 